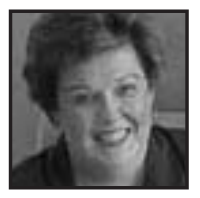

\title{
Whose Literacy Learning Landscapes Matter? Learning From Children's Disruptions
}

\author{
Mary H. Maguire, McGill University
}

\section{ABSTRACT}

This article focuses on my shifting concepts of literacy, re-researching and re-positioning about multiple literacies over decades of working with bilingual and multilingual children in diverse language contexts. I use the metaphor children's disruptions as entry points in establishing cultural dialogues about children's literacy accomplishments in multilingual contexts. Disruptions refer to children who along the way by a casual utterance, question, informal text or drawing unsettled my thinking about how languages and literacies impact on their identity, cultural positioning and ideological affiliations in different discursive spaces and diasporan communities.

\section{Reflecting Back:Re-researching and Re-positioning}

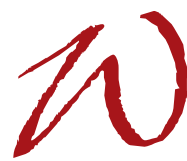

hat is literacy? What is second language literacy? These questions preoccupied me and many researchers and theorists in the 70s and $80 \mathrm{~s}$. Many looked beyond sociocognitive approaches and views of literacy as technical skills and concluded that literacy is context specific, variable and not an autonomous, monolithic concept (Street, 1985). Fagan (1998) argues that it is one thing to create a definition of literacy; it is another to situate oneself within an interpretation of literacy. Meek offered insightful comments about literacy in the early nineties as concepts of literacy shifted; her comments still resonate:

Literacy has two beginnings, one in the world, the other in each person who learns to read and write ... Behind the visible words of written texts there 
lives the writer's context, his or her life, in the world, and in the mind, in actions and in language. Language and thought meet and change each other at the bumpy intersection of literacy events. (Meek, 1991, pp.13, 35)

In the 1990s, New Literacy Studies emerged, as did new concepts such as multiliteracies, multimodal literacies and multilingual literacies (New London Group, 1996). In 2009, increasing cultural and linguistic diversity, border crossings, and new technologies calls for "New research on New and Multi Literacies" (Moje, 2009), which are as multiple as the discourses on and about literacies. I have argued that literacy practices are deeply rooted in sociocultural, historical, economic and cultural forces that are sometimes visible, sometimes invisible (Maguire, 1994, 2005). Missing in this academic rhetorical sovereignty about literacies is this question: Whose voices and perspectives about literacies and literacy landscapes really matter?

In this article, I reflect on my shifting concepts of literacy, re-researching and re-positioning about literacy and literacies over decades from working with bilingual and multilingual children in diverse language contexts. I offer bilingual/multilingual children's disruptions as entry points in establishing cultural dialogues and reflective understandings about children's literacy accomplishments in multilingual/multicultural contexts. The metaphor children's disruptions characterizes my initial curiosity about how bilingual children, and now especially multilingual children from nonmainstream backgrounds, negotiate multiple and multilingual literacies in the contexts in which they find themselves. By disruptions, I mean children who along the way by a casual utterance, question, informal text or drawing unsettled my thinking about how languages and literacies impact on their identity, cultural positioning and ideological affiliations in different discursive spaces and diasporan communities (Maguire, 2005). Using children's textual representations written over several decades, I engage in a little Foucauldian strategy-the historical episteme-ideas and knowledge debates over the decades that circumscribe what is permissible or fashionable to talk about in any historical period.

The children's disruptions I present reflect three overlapping phases in my inquiries into children's textual powers and agency, which in turn reflect the prevailing and fashionable literacy discourses in different decades: 1) Mid 1970s: Emergent literacy, biliteracy phase that focused on individual children's development; 2) Early Late 1980s: Social constructivist phase that focused on the sociocultural worlds of children from diverse backgrounds in school, classroom and family contexts; and 3) Early 1990s - present: Critical literacy and applied linguistic phase that focuses on multilingual literacies in heritage language contexts and diasporan communities. Emergent 
literacy theorists in the 1970s and early 1980s focused on individual children and their control of written language in reading and writing. In the mid 1980s, social constructivist theorists focused on children's construction of knowledge, social relationships and collaborative learning while in the early 1990s critical literacy and applied language education theorists focused on issues of social status, power relationships and social justice as manifested through class, race, gender and culture in diverse communities. The disruptions I selected are pivotal examples when children moved me from labeling them as "creative linguistic explorers" to describing them as "bilingual story writers" and readers to my present thinking that focuses on working with children and understanding their "speaking personalities," ideological becoming and positionings (Maguire, 1987, 1988; Maguire \& Graves, 2001).

\section{Entry Point 1: Emergent Literacy, Litteracie \& Biliteracy: Differentiating Language Systems}

Since the late 1970s and early 1980s my work focused on and respected bilingual primary children's generativity - their abilities_embedded in nested context of collective and personal meanings and social relationships-to imagine and create new ways of being (Maguire, 1987, 1988, 2005). Three-and-half-year-old Marie (all names are pseudonyms) first disrupted my thinking about biliteracy, niggling me from my comfortable academic pew by her French and English scribble writing as she was about to start school in a French-language kindergarten. In response to my question as to why she wanted to go to French-language school, she replied:"Because I already know English and I know how English stories work." She then produced two stories, one in English and one in French as illustrated in Figures 1 and 2.

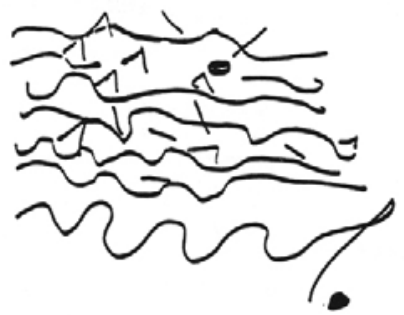

FIGURE 1. Histoire grittonnte on trançais par Marie a l'Age de 3.6 ans

Fig. 1 and Fig. 2: English and French scribble writing as two panels

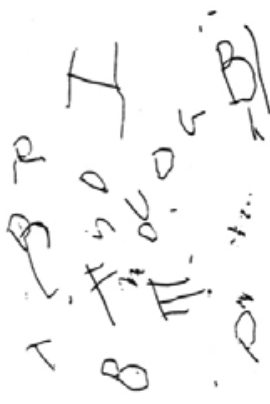

FGURE 2. Histoire grittonnee en angiais par Marie a rage de 3.6 ans 
Individual children like Marie offered many emergent textual representations that started me on a journey to understand bilingual children's positionings, hear their voices, appreciate their viewpoints and understand their identity politics in more than one language. Their discursive positionings provoked me to consider Bakhtin's sense of "new interpretive horizons" and ever new ways to mean" when conceptualizing bilingual children's textual representations. Bakhtin's dialogic theory (1986), which assumes a fusion of languages and social worlds, has been pivotal in my explaining and understanding bilingual and multilingual children's utterances and texts. Their texture efforts are not ideologically neutral nor do they occur in ideologically neutral environments such as schools, classrooms, homes and communitieswhat Bakhtin calls"contact zones" (Maguire \& Curdt-Christiansen, 2007).

Like many language and literacy theorists in the late 1970s and early 1980s (Britton, 1970; Halliday, 1978; Meek, 1991; Street, 1985), I focused on individual children's emergent literacy development. Only decades later do I have a much better understanding and appreciation for how their texts could be linked to their "ways of being" in the world. Although exciting times for researchers interested in developmental issues, very few inquiries during this era focused on biliteracy. I rejected deficit models of language and literacy, especially for children learning to read and write in more than one language and for which pejorative ways of labeling learners prevailed (At Risk in Canada, Lotes in Australia and Leps in the USA). These pernicious, pervasive prevailing discourses about literacy used explicit deficit metaphors for illiteracy such as a disease, handicap, and sickness. Regardless of chosen metaphor, children were viewed as having deficit pathologies to be eradicated and needing treatment and remediation. These discourses prioritized the alphabetic encoding of the reading process in mainstream languages and alphabetical languages as a prerequisite to learning how to read. Mainstream languages were deemed superior to other orthographies. This narrow, static view of literacy as "knowing one's letters" was not culturally or linguistically informative when applied to the processing of syllabic or logographic languages in indigenous contexts such as Cree, Mohawk or Inuktitut.

Countervailing discourses emerged as scholars challenged essentializing concepts, deficit views and resisted "a one size fits all" model of language and literacy pedagogies. Cummins' (1996) theoretically compelling construct of common underlying proficiency in second language learning was particularly attractive in explaining bilingual children's intertextuality in more than one language (Maguire, 1987). Heath's work and other scholars in early literacy (Goodman 1987; Hudelson, 1994) confirmed from their "kid watching" that children had different "ways of taking" from different literacy traditions in different communities. Even though these researchers 
positively viewed children as active participants and social actors in their language learning and social worlds, children were still perceived as essentialized homogenous groups of "kids." Some children had community designations such as Heath's "Trackton" kids; some had racial identifications as "Black," "Hispanic" or "Latino" or some had status identities as "minority language," a label that many Canadian researchers and I used uncritically. Teachers and researchers in L1 and L2 language and literacy worked in their own professional, homogenized silos, neither group talking to or with each other. Jane Miller (1983) was one of the first to argue that bilingual children were not deficient, nor stranded but poised between languages. Jezak, Painchaud and d'Anglejan (1995) were the first to use the term litteratie in French research and challenged the term alphabétisation, a term that reflects a narrow and static view of literacy in French literacy discourse as well as English. However, much discourse in this era still focused on mainstream languages rather those with different alphabetical systems such as Chinese, Japanese, Persian or Arabic, to name a few. Few considered the interplay between what Elsa Auerbach (2005) refers to as local and globalizing forces that impact on individuals' and groups' access to and uses of multiple literacies in particular contexts and communities.

\section{Entry Point 2: Moving from Literacy, Littératie to Non-Mainstream Literacies}

Two pivotal moments, Epiphanies of the Ordinary to borrow from James Joyce (cited in Bruner, 1986), disrupted my thinking once again in the mid and late 1980s. The first occurred in 1985 when teaching a course on biliteracy in a summer institute for Micronesian teachers on the Island of Pohnpei. I became aware of my own white Caucasian identity as the only "visible minority" on this island. There amidst the chatter in my lanai classroom I heard many new languages from the Astronesian family that ranged from Nauuan, Kosrian, Marshallese, Chamorro, Woleaian, Paula, Trukic, Polynesian East Carolinian, Yapese and Pohenpeian. There in the middle of the South Pacific, I was confronted by my own ethnocentrism working in mainstream languages, discovered English as an International language taking on new identities and multiple ownerships and was forced to think about not only multiple literacies but multilingual literacies. Unsettling were the local children's daily questions and disruptions to my lanai classroom on this tiny island in the South Pacific: Why are you so white? Why do you have blue eyes? Working in Micronesia unsettled my neat western categorizations about literacy and ways of looking at literacy landscapes and turning on its head my rather amateur armchair voyeurizing, 
ethnographic posing as an observer of young children to think more about inquiries and dialogues WITH multilingual children in heritage and indigenous contexts. The second Epiphany occurred locally the fall of that same year when I returned to Montreal and was working in urban diverse classroom contexts on a funded SSHRC study of "minority language children." A grade one Iranian child, Heddie, made me wrestle with new issues and how literacy was defined, written and conceptualized in non-mainstream languages and cultures from the perspectives of trilingual or multilingual children themselves (Maguire, 1999). These issues are still timely and relevant in 2009 as we live in a climate of increasing globalization and diverse demographic and migration patterns. Even today, mainstream academic discourses about literacy still prevail. Whose literacies and literacy landscapes are privileged and recognized in our classrooms and scholarly communities of literacy practices? Heddie piqued my curiosity about the meanings of children's biliteracy in non-mainstream cultures and languages as illustrated in Figure 3.

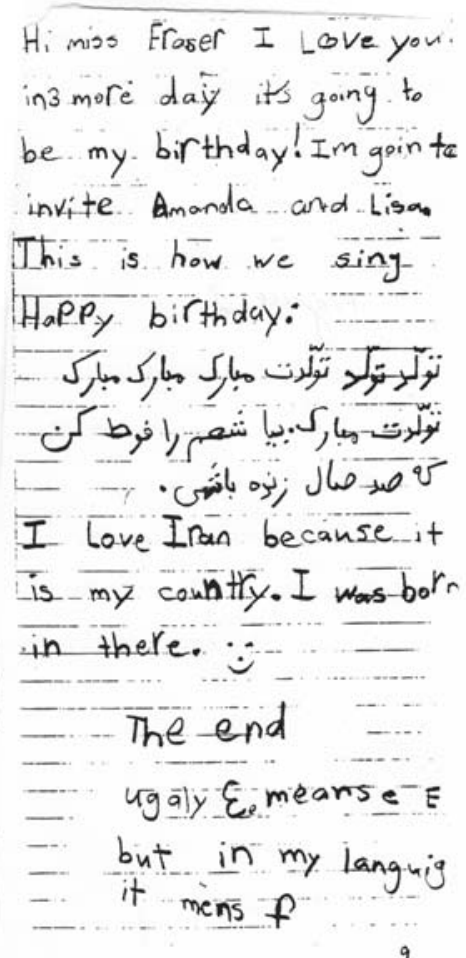

Fig. 3: Bilingual textual representations in non-mainstream languages 
This text emerges from a 1994 dialogue journal writing teacher-researcher project in a grade one classroom in a Montreal inner city school. My initial inquiries into children's biliteracy began with a three-and-half-year-old's English and French scribble writing as illustrated in Figures 1 and 2. My Vygotsksian focus on individual bilingual child story writers and their emergent literacies at the time convinced me that children's emerging construction and self-regulation of any symbolic system like written language is simultaneous with their participation in cultural dialogues with significant others. I often argued that children do not derive any language system by osmosis but from their experiences in literacy practices and how teachers and parents interpret and respond to their textual efforts. In 2009, I look at Heddie's text again and think about whose literacies are privileged in our academic conceptualizing of multiple literacies and whose literaces are included or excluded in classrooms. Still strikingly absent in the academic discourse about literacy and multiple literacies is reference to multialphabetical systems such as Chinese, Japanese, Persian, Arabic, to name a few. Children like Heddie forced me to think about more complex questions about language, learning, identity, schooling and society. For example, what kinds of people are children becoming in schools? How do multilingual children negotiate the processes of becoming a self in schools? In society? As citizens of the world? Or as ambassadors in diasporan communities-communities that know only too well the tensions and struggles between identity construction and identification with self and others. In reflecting back on my attempts to create a research space for myself that I could inhabit with imagination, integrity and credibility, I found that I could enter theoreticians' worlds such as Bakhtin (1986) and Vygotsky (1978) very easily. I have since learned that I cannot enter children's worlds so easily. I have learned to better appreciate the complexities of their sociocultural and personal worlds from their perspectives and locations as I try to understand their envisioned possibilities for selfhood, real or imagined.

Just when I thought I had discovered how bilingual children construct language for themselves and others in more than one language and context, another child, Hosi, disrupts my thinking about language and literacy with his text on Language and Hair:

All my friends at Saturday school speak Japanese. They all have black hair. But my friends at English schools do not. My best friend, Daniel speaks English and has blond hair. Jennifer has black hair like me but she is Chinese. Bejan speaks French and he has dark brown hair, friends at English school has all kinds of color hair and speaks all kinds of language. But we all speak English in class. I like both English and Japanese very much. I like my friends very much. (Ishibashi, 1993) 
Speaking in the present tense, Hosi talks about his classmates who all speak English and different languages and have different color hair but are friends. However, it would be a decade before I conducted inquiries in heritage language contexts such as our Multilingual Research Group's Heritage Languages Project (Maguire, 2007). Despite my strong child advocacy stance, I was still "othering" children as minority language children or students-a subject position that is distinct from persons, or friends.

\section{Entry Point Three: Social Constructivist Phase Appreciating the Complexity of Multilingual Children's Textual Representations}

By the late 1980s and early 1990s, many social constructivists (Wertsch, 1991) argued that as children engaged in relational activities with others, they appropriated and self-regulated their literacy actions by assuming a sense of agency in the coming-to-know process. There began the era of more contextualized, situated sociocultural perspectives, multiple ways of looking at identity and consideration of the myriad relational possibilities. Like many social constructivists, I located my research activities in traditional venues such as schools and teachers' classrooms-institutional venues inscribed with the power to name, label, to recognize or not. Hybrid identities, multiple identities, ethnolinguistic youth became the new labels for characterizing what minority language children did and/or did not do and who they were. By the mid 1990s, this social constructive turn led researchers influenced by Vygotsky (1978) to begin talking about the complex intersections among languages, cultures, communities and classrooms. The next text invited me to further think about the complexities of children's textual representations and different types of mapping of social relations that are possible within one text just as Multiple Literacies had become the new fashionable discourse about literacy.

During this era the emergence of New Paradigm Diversity (Denizen \& Lincoln, 2000) brought new motions that came in multiplexes. Everything seemed to be in multiples, multiple voices, multiple realities, multiple literacies and multiple forms of representation, multiple interdisciplinary approaches, multiple perspectives to knowledge construction, multiple discourses, multiple tensions and multiple challenges. Although I intellectually thought I understood these academic discourses, Sadda disrupted my thinking about children's textual representations to consider critical literacy and more critically examine literacy as a negotiation of one's 
orientation towards written language through one's discursive positioning within multiple forms of complex relations of power and status as illustrated in Figure 4.

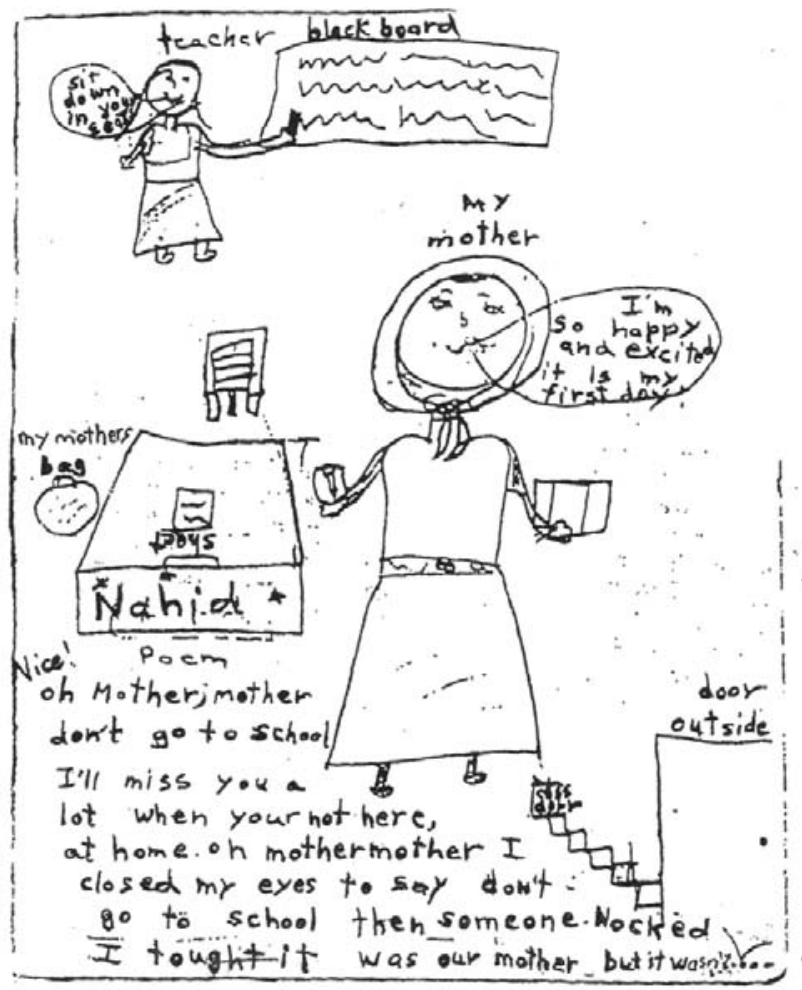

Fig. 4: Sadda - a grade 3 Iranian multilingual child and multiple textual representations

This text emerged from another Social Sciences and Humanities Research Council (SSHRC) funded study of minority language primary children's negotiation of literacy practices and cultural positioning in home and schools contexts. I use and continue to use this text in my multilingual literacies course as a stunning example of a voice-centered relational approach that views children as embedded in a complex web of intimate and larger social relations and discourses and what Bakhtin calls "sympathetic co- experiencing" (Bakhtin, 1986; Maguire \& Graves, 2001). I ask my students to engage these questions: What has Sadda appropriated? What is she reifying or resisting in this text? Her evaluative stance towards her social worlds-the most immediate one of which is her mother's situation as a second language learner, demonstrates her internalization of the indexical signs of modernist literacy practices and discourses of schools and classrooms. Her evocative poem addressed to her 
mother with a plea not to go to night school is juxtaposed with her mother's voice and expressed delight of attending school in a dialogic bubble: "I'm so happy and excited. It is my first day." Her drawing includes the traditional, modernist semiotic resources and tools of school learning situations, such as a teacher, a blackboard, a school desk and chart, her mother's school bag and a sheet of paper. She represents diverse social roles and subject positions as student and teacher, mother and daughter through complex multiple representations. Giving voice to multilingual children's perspectives on becoming and being multiliterate requires a continual audit of the meaning of their contextual worlds where subtle shifts and slides of meanings collide, occur and reoccur (Maguire, 1997, 1999).

Writing is a critical resource for the development of multilingual children's textual powers, agency and writing identity multiple languages. I use the term "textual powers" to refer to children's sense of agency to use and create texts as resources to represent aspects of human experiences, self and identity. Children's texts in more than one language offer interesting insights into their envisioned possibilities of selfhood and writing identity (Ivanic, 1998). Ivanic argues that "writing is an act of identity in which people align themselves with socioculturally shaped possibilities of selfhood playing their part in reproducing or challenging dominant practices and discourses, and the values, beliefs and interests which they embody" (p. 31). The textual powers of Lingling, a trilingual child author who claimed an authorial self in three languages, Chinese, English and French (Curdt-Christiansen \& Maguire, 2007), have been previously documented elsewhere. She is just one of the many trilingual or multilingual children who have had opportunity to encounter the last decade working in trilingual literacy contexts. They frequently reflect on their own sense of self, their insider and outsider status, their sense of belonging, race and ethnicity. They have their own articulate preferences for the multiple schools and literacy practices they are asked or required to or volitionally engage and through their textual powers reveal a trace of their own ideological becoming and affiliations (Maguire \& CurdtChristiansen, 2007). 


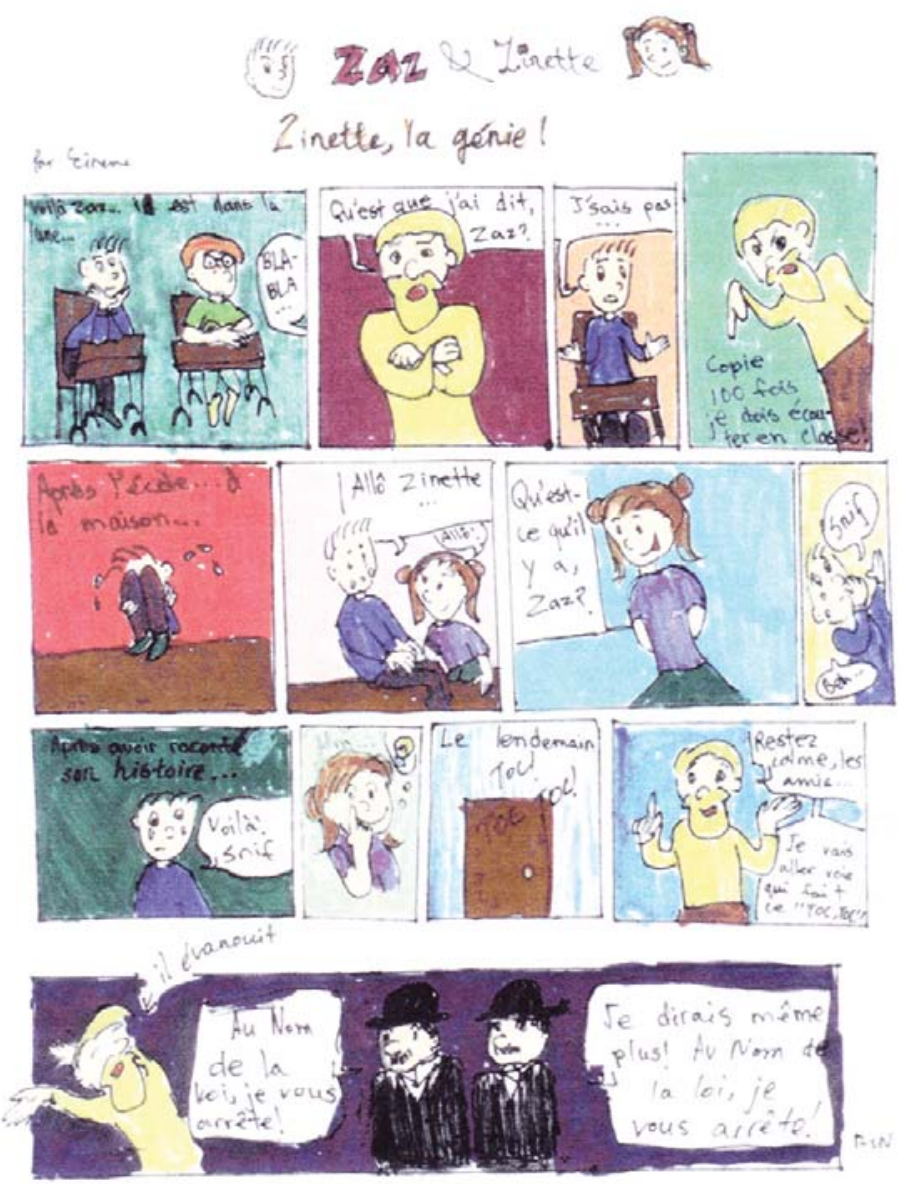

Fig. 5: Zaz \& Zinette comic strip

Lingling's text, Zinette, la génie!, disrupted my thinking about multiple literacies, multimodal literacies and multilingual literacies and forced me to consider new questions about writing and literacies in multiple languages. Lingling reads and creates comics in English, Chinese and French (Curdt-Christiansen \& Maguire, 2007). This self-initiated French comic strip textual endeavor illustrates her agency in creating texts that disrupt the social order in her third language! Do children's particular discourse choices support particular ideologies and representational perspectives of knowledge making and social orders in particular contexts or languages? As this 
generation of multilingual young people grows to adulthood, what literacies will they value and embrace, resist or discard? What loyalties will they retain or reject? What languages will they choose to speak, read and write? How will they define their individual and collective identities? What and/or who will they define as their community or communities, or communities of practices? Social institutions and power relationships pattern literacy practices, and some literacies become more dominant, visible and influential than others. And why? The answer to these questions requires a continual audit of Literacy Life Worlds (spaces for community life where local and specific meanings can be expressed, represented, shared and understood) and Worlds of Literacy (distinct literacies that exist alongside each other in complex societies-each with their own historical literacy trajectories).

\section{Revisiting and Rethinking Multiple Literacies, Literacy Signs: Reading the Signs and World of Literacies}

"Literacy" is now viewed as complex social practices and ways of knowing, being and becoming, believing, doing and valuing. New Literacy theorists argue that literacy practices are always rooted in particular worldviews that reflect the values, cultures and patterns of privileges in different social, cultural, linguistic, political contexts (Gee, 1996; Luke 2003; Street, 1985, 2008). They maintain that reading, writing and meanings are always situated within specific practices, specific Discourses (Gee), and I would add nested contexts (Maguire, 1994). As Sadda's text reveals, there is always more than one context intersecting with literacy practices. Literacy events, practices, activities replace literacy skills, tasks, narrow concepts of reading and writing such as learning letters. The term practices, central in the New Literacy Studies approach to literacy, is used in two ways: (1) To refer to observable, collectable or documentable specific ethnographic details of situated literacy events, involving real people, relationships, purposes, actions, places, times, feelings, tools and resources. The term "practices" in this sense often contrasts with and complements the term "texts," since it refers to those other aspects of literacy beyond the text itself; and (2) To refer to culturally recognizable patterns of behavior that can be discerned from specific literacy activities around "texts." The term "practices" in this sense often includes "textual practices," the culturally recognizable patterns for constructing texts. The New London Group (1996) also uses the term multimodal literacies to include the range of modalities, printed words, still and moving images, sound speech, music and color-that authors combine to design texts. Literate practices refer to specific sways of utilizing literacy shaped by the values, interests and 
knowledge-making practices of particular communities. Literate activity refers to the broad spectrum of actions of particular communities.

New conceptualizations of literacy have led to new ways of naming literacy/literacies: In 2003, Kress referred to Multimodal Literacies while Martin-Jones and Jones edited a collection of articles about Multilingual Literacies and Cope and Kalantzis (2008) talk about Multiliteracies. These significant epistemological changes in concepts and conceptualizing literacy have led to a rich lexicon of literacy definitions. Some are: traditional literacy, functional literacy, cultural literacy, media literacy, visual literacy, computer literacy, scientific literacy, musical literacy, spiritual literacy, health literacy, emergent literacy, family literacy, technical literacy, local literacy, community literacy, city literacies, world literacies, indigenous literacies, vernacular literacies, civic literacy, ecological literacy, biliteracy, multiliteracies, and multilingual literacies. To what extent is it appropriate and useful to distinguish between and among these uses of the term "literacy"?

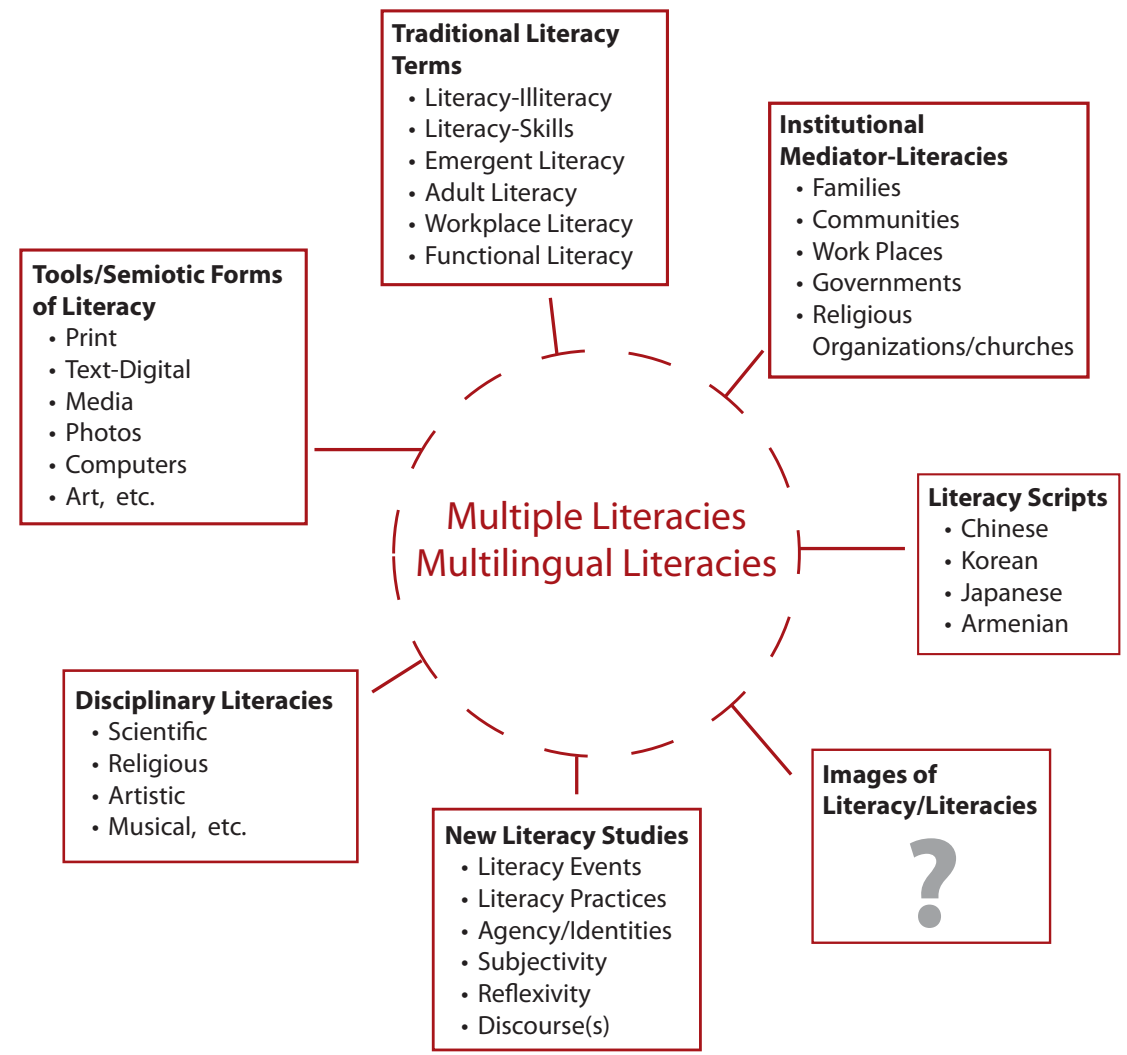

Fig. 6: Multiple Literacies, Multilingual Literacies 
Indeed there are myriad ways to focus on contemporary understandings of multiple literacies as a complex set of social practices in diverse multilingual and multicultural contexts. In learning specific literacy practices, children are not just developing technical skills but are taking on particular identities and values associated with them. Thus, different literacy practices position children differently in socio-culturallinguistic-political spaces. This view of literacy practices assumes that literacy learning and literacy development is connected with much deeper cultural values about identity, personhood and relationships. The concept of "literacy event" (Heath, 1983) highlights the mediation of texts through dialogue and social interactions in the contexts of particular practices and settings. The concept of "literacy practice" incorporates events, and people's individual and collective beliefs and understandings about them.

In 2005 The Executive of the National Council of Teachers of English approved a summary statement developed by the Multimodal Literacies issue team that calls for declarative statements concerning the broadest definitions of multimodal literacies:

It is the interplay of meaning-making systems (alphabetic, oral, visual, etc.) that teachers and students should strive to study and produce. "Multiple ways of knowing" also includes art, music, movement and drama, which should not be considered curricular luxuries.

In 2008, the Executive of the National Council of Teachers of English included this statement about literacy on their Web site:

Literacy has always been a collection of cultural and communicative practices shared among members of particular groups. As society and technology change, so does literacy. Because technology has increased the intensity and complexity of literate environments, the twenty-first century demands that a literate possess a wide range of abilities and competencies, many literacies. These literacies—from reading online newspapers to participating in virtual classrooms - are multiple, dynamic, and malleable. As in the past they are inextricably linked with particular histories, life possibilities and social trajectories of individuals and groups.

In all this diverse conceptualizing of literacies, a missing dimension is reference to Heritage Literacy and Literacies in languages other than dominant ones, and what these multiple, multimodal and multilingual literacies might look like in diverse 
languages. Heritage literacies involve complex intergenerational, interlingual literacy practices, beliefs, values and ways of knowing. These context-specific literacy practices are embraced, adapted or rejected by learners within and across generations. They reflect the choices individuals and communities make about literacy practices, identities and identity politics. Although Montreal is a North American city with the highest number of trilingual students and reported highest retention of languages other than dominant mainstream languages, we know very little about multilingual literacies and identity politics within these heritage contexts. I return to my question signaled in my title: Whose Literacies and Literacy Landscapes matter?

\section{References}

Auerbach, E. (2005). Connecting the Local and the Global: Pedagogy of Not-Literacy. In Anderson, H.; Kendrick, M. Rogers, T. \& Smythe, S. (Eds) Portraits of Literacy Across Families, Communities, and Schools (363-380). Mahwah, NJ: Lawrence Erlbaum Associates.

Bakhtin, M. M. (1986). The dialogic imagination: Four essays. (Translated by Caryl Emerson and Michael Holquist. Edited by Michael Hosquist) Austin: University of Texas Press.

Britton, J. (1970). Language and learning. Harmondsworth, England: Penguin Books.

Bruner, J. (1986). Actual minds: Possible worlds. Cambridge, MA: Harvard University Press.

Cope, B., \& Kalantzis, M. (2008). Language Education and Multiliteracies. In May, S. \& Hornberger, N. (Eds). Encykopedia of Language and Education. $2^{\text {nd }}$ edition, Vol. 3. Language Policy and Political Issues in Education, 195-211. Amsterdam, Holland: Springer Science.

Cummins, J. (1996). Negotiating identities: Education for emppowerment in a diverse society. Ontario, CA: California Association for Bilingual Education.

Curdt-Christiansen, X., \& Maguire, M. H. (2007). Self, Voice and Discursive Identity Constructions: The Textual Powers of Three Trilingual Chinese Girls. In Thiessen,
D. \& Cook-Sather, C. (Eds). International Handbook of Students' Experiences of Elementary and Secondary School (517554). Springer (Dorech): Netherlands Publishers.

Denizen, N. K., \& Lincoln, Y. S. (Eds) (2000). Handbook of qualitative research. Thousand Oakes: Sage.

Fagan, W. (1998). Literacy for living. Newfoundland; Institute of Social \& Economic Research Memorial University.

Gee, J. P. (1996). Social linguistics and literacies. London: Routledge.

Goodman, Y. (1987). Kid watching: Observing children in the classroom. In Jaggar, A. \& Smith- Burke, M. T. (Eds.). Observing the Language Learner. Newirk, DE: International Reading Association and Urbana, IL: National Council of Teachers of English.

Halliday, M. A. K. (1978). Language as a social semiotic. The social interpretation of language and meaning. Baltimore: University Park Press.

Heath, S. B. (1983). Ways with words: Language, life and work in communities and classrooms. Cambridge: Cambridge University Press.

Hudelson, S. (1994). Literacy development of second language children. In F. Genesee (Ed). Educating second language children: 
The whole childe, the whole curriculum, the whole community. Cambridge: Cambridge University Press.

Ishibashi, T. (1993). Multiple ways of looking at bilingual children's writing: Case studies of Japanese children learning in an elementary school and their home contexts. Unpublished manuscript. Faculty of Education Library. McGill University, Montreal.

Ivanic, R. (1998). Writing and identity: Discoursal construction of identity in academic writing. Philadelphia: John Benjamins.

Jezak, M., Painchaud, G., \& d'Anglejan, A. (1995). Rehaussement des exigences langagieres en milieu de travail: l'etat de la recherche. Revue des sciences de l'education, 21(1), $1-18$.

Kress, G. (2003). Literacy in the New Media Age. London: Routledge

Luke, A. (2003). Literacy and the other: A sociological approach to literacy research and policy in multilingual societies. Reading Research Quarterly 38, 132-141.

Maguire, M. H. (1987). Is writing a story that more complex in second language learning than in a first language? Children's perceptions. Carleton Papers in Applied Language Study 4, 17-63.

Maguire, M. H. (1988). How do they tell? Écrire c'est choisir. In Meek, M. \& Mills, C. (Eds.) Language and Literacy in the Primary School. London: Falmer Press.

Maguire, M. H. (1994). Cultural stances of two Quebec bilingual children informing storytelling. Comparative Education Review 38(1), 115-144.

Maguire, M. H. (1997). Shared and negotiated territories: the socio-cultural embeddeness of children's acts of meaning. In A. Pollard, D. Thiessen, \& A. Filer (Eds.) Children and their curriculum. The perspectives of primary and elementary school children (51-80). London: Falmer Press.

Maguire, M. H. (1999). A bilingual child's choices and voices: Lessons in listening, noticing and understanding. In E. Franklin (Ed). Reading and writing in more than one language. (115-149) Alexandria, VA:TESOL.
Maguire, M. H. (2005). Identity and Agency in Multilingual Children's Cultural Worlds: Third Space and Heritage Languages. In Cohen, J. McAlister, K. Rolstad, K., \& MacSwan, J. (Eds.) Proceedings $4^{\text {th }}$ International Symposium on Bilingualism (1423-1445). Summerville, MA: Cascadilla Press.

Maguire, M. H. (2007). Reflections on Researching in Multilingual Contexts. International Journal of Sociolinguistic Studies, 1(1), Equinox Press, 5-24.

Maguire, M. H., \& Curdt-Christiansen, X. (2007). Multiple Schools, Languages and Experiences and Affiliations. Ideological Becoming and Positionings. Heritage Language Journal (online journal).

Maguire, M. H., \& Graves, B. (2001). Speaking Personalities in Primary School Children's L2 Writing. TESOL Quarterly, 35(4), 561-593.

Martin-Jones, M., \& Jones, K. (Eds.) (2003). Multilingual literacies: Reading and writing in different worlds. Philadelphia: John Benjamins.

Meek, M. (1991). On being literate. Portsmouth: Heineman.

Miller, J. (1983). Many voices: Bilingualism, culture and education. London: Routledge \& Kegan Paul.

Moje, E. B. (2009). A Call for New Research on New and Multi Literacies. Research in the Teaching of English, 43(4), 348-362.

National Council of Teachers of English (2005). Retrieved November 24, 2009, from http://www.ncte.org/governance/Multim odalLiteracies

National Council of Teachers of English (2008). Retrieved November 24, 2009, from http://www.ncte.org/governance/literacies

New London Group (1996). A pedagogy of multiliteracies: Designing Social Futures. Harvard Education Review 66(1), 60-92.

Street, B. (1985). Social literacies: Critical approaches to literacy development, ethnography and education. London: Longman.

Street, B. (2008). New literacies, new times: Development in literacy studies. 
Vygotsky, L. S. (1978). Thought and language. Cambridge: MIT Press.
Wertsch, J. (1991). Voices of the mind: A sociocultural approach to mediated action. Cambridge, MA.

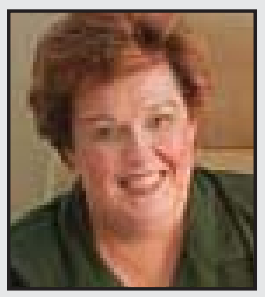

Mary H. Maguire, Ph. D, a former secondary school English teacher, is a Full Professor in the Department of Integrated Studies in Education in the Faculty of Education at McGill University. Her many Social Sciences and Humanities Research Council (SSHRC) funded studies have resulted in publications on bilingual and multilingual children's identity, agency, textual powers and voice in home, school and community contexts. Her current research interests are on multilingual literacies, narrative inquiry, narrative medicine, patient voice and perspective. 